\title{
Karakteristik Pasien Tumor Orbita Di PMN RS Mata Cicendo Bandung Periode 2017-2018
}

\author{
*Ira Citra Ningrom ${ }^{1}$, Susiyadi ${ }^{1}$, Andi Muh. Maulana ${ }^{1}$, Raudatul Janah ${ }^{2}$ \\ ${ }^{1}$ Program Studi Pendidikan Dokter Fakultas Kedokteran Universitas Muhamadiah Purwokerto \\ ${ }^{2}$ Staf Medik Fungsional Laboratorium Patologi Anatomi PMN RS Mata Cicendo Bandung
}

\author{
*) Correspondence Author \\ Ira Citra Ningrom ${ }^{1}$ \\ Departemen Patologi Anatomi, Fakultas Kedokteran, \\ Universitas Muhammadiyah Purwokerto, Purwokerto 53113, Indonesia \\ Email: kyakyu15@yahoo.com \\ Telepon: +6282242490887
}

\begin{abstract}
Orbital tumors are tumors that occur in the orbital area where they can affect the outside of the orbital and the inside of the orbit. At present, it is still rare to report the prevalence of orbital tumors in the world. In developing countries such as Indonesia, reports on the incidence of orbital tumors are also rarely reported. Diagnosis and appropriate therapy if we recognize the characteristics of these orbital tumors. The purpose of this study was to determine the characteristics of orbital tumor patients at PMN Cicendo Eye Hospital Bandung. This research is a descriptive observational study with cross sectional method with total sampling technique. Data were collected retrospectively based on medical records in the form of age, sex, eyes involved, tumor location, surgery, clinical diagnosis, and histopathological results. The results showed that orbital tumors with the majority of age $>45$ years (43.3\%), male gender (55.4\%), involvementof the left ocular eye (51.18\%), with the most frequent location not in the conjunctiva, palpebral and retrobulbar $(36.8 \%)$, clinical diagnosis of benign tumors $(68.3 \%)$ were cysts $(22.4 \%)$, the most histopathological results of benign tumor lesions (71.4\%) were inflammation (17\%). So it can be concluded that knowing the characteristics of this orbitaltumor will have an impact on the therapy given will be appropriate.
\end{abstract}

Keywords: orbital tumor, characteristics, cicendo eye hospital

\begin{abstract}
Abstrak
Tumor orbita adalah tumor yang terjadi pada daerah orbita dimana bisa mengenai bagian luar orbita dan bagian dalam orbita. Saat ini, masih jarang dilaporkan tentang prevalensi tumor orbita di dunia. Di negara berkembang seperti di Indonesia laporan angaka kejadian tumor orbita juga masing jarang dilaporkan. Diagnosis dan terapi yang tepat bila kita mengenal karakteristik tumor orbita ini. Tujuan penelitian ini yaitu mengetahui karakteristik pasien tumor orbita di PMN RS Mata Cicendo Bandung. Penelitian ini merupakan penelitian deskriptif observasional metode cross sectional dengan teknik total sampling. Data dikumpulkan secara retrospektif berdasarkan catatan medis berupa umur, jenis kelamin, mata yang terlibat, lokasi tumor, tindakan operasi, diagnosis klinis, dan hasil histopatologi. Hasil penelitian menunjukkan bahwa tumor orbita sebanyak 760 penderita dimana mayoritas umur $>45$ tahun $(43,3 \%)$, jenis kelamin laki-laki $(55,4 \%)$, keterlibatan mata ocular sinistra $(51,18 \%)$, dengan lokasi tersering bukan di conjungtiva, palpebral dan retrobulbar $(36,8 \%)$, diagnosis klinis tumor jinak $(68,3 \%)$ berupa kista $(22,4 \%)$, hasil histopatologis terbanyak lesi tumor jinak $(71,4 \%)$ berupa peradangan $(17 \%)$. Sehingga dapat disimpulkan dengan mengetahui karakteristik tumor orbita ini nantinya akan berdampak terapi yang diberikan akan tepat.
\end{abstract}

Kata Kunci : tumor orbita, karakteristik, rumah sakit cicendo 


\section{PENDAHULUAN}

Tumor orbita merupakan tumor yang letaknya di orbita yang dapat mengenai jaringan penyangga, kelenjar air mata, dan jaringan saraf pada mata. Berdasarkan posisi susunan anatominya tumor orbita dibagi menjadi tiga yaitu : 1) tumor eksternal, yaitu tumor yang tumbuh di bagian luar mata, seperti tumor palpebra (tumor yang tumbuh pada kelopak mata) dan tumor konjungtiva (tumor yang tumbuh pada lapisan konjungtiva yang melapisi mata bagian depan); 2) tumor intraokuler, yaitu tumor yang tumbuh di dalam bola mata; dan 3) tumor retrobulbar, yaitu tumor yang tumbuh di belakang bola mata. ${ }^{1}$

Kasus tumor orbita ini sangat jarang terjadi sehingga masih sedikit informasi mengenai prevalensi epidemiologi di dunia. Ada yang menyebutkan angka kejadian tumor orbita hanya sekitar $1 \%$. Tumor orbita ini dapat dibagi menjadi tumor orbita primer, tumor orbita sekunder atau metastasis. Menurut Amemiya et al., (2002) melaporkan data kasus tumor orbital metastatik di jepang pada tahun 1903-1998 ditemukan 128 penderita dimana 74 dengan jenis kelamin lakilaki, 52 jenis kelamin perempuan, dan 2 penderita tidak teridentifikasi. ${ }^{1,2}$

Tumor orbita berdasar sifatnya dapat bersifatjinak dan dapat bersifat ganas. Pendekatan terapinya juga berdarkan sifat tumor tersebut, dimana tumoryang jinak hanya dilakukan terapi eksisi atau konserfatif sedangkan tumor yang ganas dilakukan terapi biopsi dilanjutkan dengan radioterapi dan kemoterapi. Adapun prognosis dan angka keberhasilan kelangsungan hidup 5 tahun ( 5 years survival rate) penderita tumor orbita mencapai $80 \%$, artinya harapan hidup masih cukup baik, namun menimbulkan masalah yang besar karena penderia mengalami kehilangan tajam penglihatan serta mengakibatkan kecacatan baik kosmetik maupun kematian..$^{3,4}$

Data mengenai tumor orbita di Indonesia masih sangat jarang dilaporkan. Padahal dimana diagnosis yang tepat didapatkan bila mengenal karakteristik penyakit tumor orbita ini dengan baik sehingga terapi yang akan diberikan akan tepat. Berdasarkan permasalahan tersebut peneliti ingin meneliti karakteristik pasien tumor orbita di PMN RS Mata Cicendo Bandung periode tahun 2017-2018.

\section{METODE}

Desain penelitian ini observasional retrospektif dengan desain studi cross sectional. ${ }^{5}$ Teknik pengambilan sampel secara total sampling yaitu mengambil seluruh populasi menjadi sampel. Pengambilan data dilakukan dari rekam medis pasien dengan diagnosis tumor orbita di PMN RS Mata Cicendo Bandung periode 2017-2018. Data dikelompokkan menurut umur, jenis kelamin, mata yang terlibat, lokasi tumor, tindakan operasi, diagnosis klinis, dan hasil histopatologi. Diungkapkan dalam data frekuensi. 
Kriteria inklusi penelitian ini adalah semua pasien yang terdaftar sebagai pasien tumororbita di PMN RS Mata Cicendo Bandung. Kriteria eksklusi penelitian ini adalah pasien dengan rekam medis yang tidak dapat ditemukan di PMN RS mata Cicendo Bandung. ${ }^{6}$

\section{HASIL}

Berdasarkan tabel 1 diketahui bahwa karakteristik pasien berdasarkan usia sebanyak 185 orang $(24,3 \%)$ memiliki rentang usia $<17$ tahun, sebanyak 245 orang $(32,2 \%)$ memiliki rentang usia $17-45$ tahun dan sisanya sebanyak 330 orang $(43,4 \%)$ memiliki rentang usia >45 tahun. Hasil uji tersebut memberikan gambaran bahwa pasien tumor orbita dalam penelitian ini mayoritas usia $>45$ tahun.

Berdasarkan tabel 2 diketahui bahwa karakteristik pasein berdasarkan jenis kelaminsebanyak 421 orang $(55,4 \%)$ merupakan laki-laki dan sisanya sebanyak 339 orang $(44,6 \%)$ merupakan perempuan. Hasil uji tersebut memberikan gambaran bahwa pasien tumor orbita dalam penelitian inimayoritas laki-laki.

Berdasarkan tabel 3 diketahui bahwa Keterlibatan mata pasien tumor orbita sebanyak 371 orang $(48,8 \%)$ berada di Od (okular desktra) sedangkan sisanya sebanyak 389 orang $(51,18 \%)$ berada di Os (okular sinestra). Hasil uji tersebut memberikan gambaran bahwa pasien tumor orbita dalam penelitian ini mayoritas melakukan operasi pada lokasi

Os (okular sinestra).

Berdasarkan tabel 4 diketahui bahwa dari lokasi operasi OD (okulalar desktra) sebanyak 130orang (35\%) ada pada palpebra, sebanyak 88 orang $(23,7 \%)$ berada pada conjungtiva, sebanyak 20 orang $(5,4 \%)$ berada pada retrobulbar dan sisanya sebanyak 133 orang $(35,8 \%)$ berapada pada lainnya. Hasil uji tersebut memberikan gambaran bahwa pasien tumor orbita yang melakukan operasi di OD (okular desktra) mayoritas berada pada lainnya.

Berdasarkan tabel 5 diketahui bahwa dari lokasi operasi OS (okular sinistra) sebanyak 140 orang (36\%) ada pada palpebra, sebanyak 77 orang $(19.8 \%)$ berada pada conjungtiva, sebanyak 29 orang $(7,5 \%)$ berada pada retrobulbar dan sisanya sebanyak 143 orang $(36,8 \%)$ berapada pada lainnya. Hasil uji tersebut memberikan gambaran bahwa pasien tumor orbita yang melakukan operasi di OS (okular sinistra) mayoritas berada pada lainnya.

Berdasarkan tabel 6 diketahui bahwa jenis tindakan operasi yang dijalani oleh responden sebanyak 277 orang $(36,4 \%)$ merupakan biopsi, sebanyak 14 orang $(1,8 \%)$ merupakan biopsi seksi, sebanyak 6 orang $(0,8 \%)$ merupakan Biopsi insisi, sebanyak 21 orang $(2,8 \%)$ merupakan Orbitomi, sebanyak 73 orang $(9,6 \%)$ merupakan Enukleasi. sebanyak 92 orang (12,1\%) 
merupakan Biopesi ekstirpasi, sebanyak 91

orang (12\%) merupakan Biopesi eksisi dan sisanya sebanyak 186 orang $(24,5)$ merupakan operasi lainnya. Hasil uji tersebut memberikan gambaran bahwa pasien tumor orbita dalam penelitian ini mayoritas melakukan operasi Biopsi.

Berdasarkan tabel 7 diketahui bahwa dari hasil diagnosis sebanyak 519 orang $(68,3 \%)$ didiagnosis berada pada lesi/tumor jinak dan sisanya sebanyak 241 orang $(31,7 \%)$ didiagnosis memiliki lesi/tumor ganas. Hasil uji tersebut memberikan gambaran bahwa tumor orbita pada penelitian ini mayoritas memiliki lesi/tumor jinak.

Berdasarkan tabel 8 diketahui bahwa dari hasil diagnosis Lesi/Tumor jinak sebanyak 24 orang $(4,6 \%)$ memiliki veruka, sebanyak 116 orang $(22,4 \%)$ memiliki kista, sebanyak 68 orang $(13,1 \%)$ memiliki nevus, sebanyak 27 orang $(5,2 \%)$ memiliki granuloma/radang, sebanyak 34 orang $(6,6 \%)$ memiliki Ossn, sebanyak 92 orang $(17,7 \%)$ memiliki massa dan sebanyak 115 orang $(22,2 \%)$ memiliki propotosis/massa retrobulbar. Hasil uji tersebut memberikan gambaran bahwa pasien tumor orbita pada Lesi/Tumor jinak mayoritas adalah kista.

Berdasarkan tabel 9 diketahui bahwa dari hasil diagnosis Lesi/Tumor ganas sebanyak 25 orang $(10,4 \%)$ memiliki SCC, sebanyak 25 orang $(10,4 \%)$ memiliki BCC, sebanyak 50 orang $(20,7 \%)$ memiliki Retinoblastoma, sebanyak 27 orang $(11,2 \%)$ memiliki Melanoma, sebanyak 1 orang $(0,4 \%)$ memiliki Sebaseous Carcinoma, sebanyak 55 orang $(22,8 \%) \quad$ memiliki Limfoma maligna/NHML, sebanyak 11 orang $(4,6 \%)$ memiliki Meningioma, sebanyak 5 orang $(2,1 \%)$ memiliki Glioma dan sisanya sebanyak 42 orang $(17,4 \%)$ memiliki lainnya. Hasil uji tersebut memberikan gambaran bahwa pasein tumor orbita pada Lesi/Tumor ganas mayoritas adalahLimfoma maligna/NHML.

Berdasarkan tabel 10 diketahui bahwa dari hasil histopatologi sebanyak 543 orang $(71,4 \%)$ disimpulkan berada pada lesi/tumor jinak dan sisanya sebanyak 217 orang $(28,6 \%)$ disimpulkan memiliki lesi/tumor ganas. Hasil uji tersebut memberikan gambaran bahwa pasien tumor orbita pada penelitian ini mayoritas disimpulkan memiliki lesi/tumor jinak.

Berdasarkan tabel 11 diketahui bahwa dari hasil histopatologi lesi/tumor jinak yaitu sebanyak11 orang (2\%) memiliki vitreal hemoragik, sebanyak 92 orang (17\%) memiliki radang, sebanyak 68 orang $(12,5 \%)$ dengan epithelial cyst, sebanyak 48 orang $(6,6 \%)$ memiliki kista dermoid, sebanyak 17 orang $(3,1 \%)$ memiliki kista epidermoid, sebanyak 29 orang (5,3\%) memiliki Ossn, sebanyak 85 orang $(15,7 \%)$ memiliki epitelial jinak lain, 
sebanyak 76 orang (14\%) memiliki nevus, sebanyak 11 orang (2\%) memiliki neurogenik jinak, sebanyak 29 orang $(5,3 \%)$ memiliki mesenkim jinak, sebanyak 8 orang $(1,5 \%)$ memiliki lakrimal jinak, sebanyak 38 orang (7\%) memiliki Vaskuler dan sisanya sebanyak 43 orang (8\%) memiliki limfoid hiperplasia. Hasil uji tersebut memberikan gambaran bahwa tumor orbita pada kesimpulan memiliki lesi/tumor jinak secara mayoritas menderita radang.

Berdasarkan tabel 12 diketahui bahwa dari hasil histopatologi lesi/tumor ganas yaitu sebanyak 10 orang (4,4\%) memimiliki Meningioma, sebanyak 94 orang (43,3\%) memiliki Epitel ganas, sebanyak 18 orang $(8,3 \%)$ memiliki Adneksa ganas, sebanyak 8 orang $(3,7 \%)$ memiliki Kelenjar lacrimal ganas, sebanyak 7 orang $(3,2 \%)$ memiliki Sarcoma, sebanyak 26 orang (12\%) memiliki limfoma/limfoid ganas, sebanyak 3 orang $(1,4 \%)$ memiliki Metastasis dan, sebanyak 51 orang (23,5\%) memiliki Rerinoblastoma.Hasil uji tersebut memberikan gambaran bahwa responden pada kesimpulan memiliki lesi/tumor ganas secara mayoritas menderita Epitel ganas.

Berdasarkan tabel 12 diketahui bahwa dari hasil histopatologi epithelial ganas yaitu sebanyak 24 orang $(25,3 \%)$ menderita BCC, sebanyak 23 orang $(24,7 \%)$ menderita Melanoma sedangkansisanya sebanyak 47 orang (50\%) menderita SCC. Hasil uji tersebut memberikan gambaran bahwa responden pada kesimpulan memiliki Epitel ganas secara mayoritas menderita SCC.

Berdasarkan tabel 13 diketahui bahwa dari hasil kesimpulan responden yang memiliki Adneksa ganas sebanyak 17 orang $(94,4 \%)$ menderitaDuctaleccrin ca dan sisanya sebanyak 1 orang $(5,4 \%)$ menderita sebaseus ca. Hasil uji tersebut memberikan gambaran bahwa responden pada kesimpulan memiliki Adneksa ganas secara mayoritas menderita Ductaleccrin carcinoma.

Berdasarkan tabel 14 diketahui bahwa dari hasil kesimpulan responden yang memiliki Kelenjar lacrimal ganas sebanyak masing-masing 3 orang $(37,5 \%)$ menderita ADDC, mukoepdermoid carcinoma sebnayak 1 (12,5\%), Adenoca lacrimal, sebanyak 3 orang $(37,5 \%)$ menderita Mucoepidermoid carcinoma sedangkan Malignant mix tumor sebanyak $1(12,5 \%)$.

\section{PEMBAHASAN}

Tumor orbita merupakan tumor yang jarang terjadi biasanya terletak pada rongga orbita. Tumor tersebut menjadi tantangan terbesar bagi oftalmologis karena gejala dan tanda yang ditimbulkan sangat bervariasi, sehingga dalam diagnosis pada stadium awal sering 
mengalami kesulitan. Rongga orbita berisi

bermacam-macam jaringan sehingga

semuanya mempunyai kemungkinan dapat

berkembang menjadi suatu neoplasma baik

jinak maupun ganas. ${ }^{2,13}$

Kasus tumor orbita sangat jarang terjadi kirakira hanya 1\%. Menurut American Cancer (2018), terjadi 3. 540 kasus tumor baru terutama tumor ganas dimana kebanyakan merupakan melanoma mata dan bola mata yang masuk kedalam tumor orbita. Dari laporan tersebut menyatakan sebanyak 2.130 kasus dialami oleh laki-laki dan 1.410 dialami oleh wanita. Hal ini sejalan dengan penelitian ini dimana hasil penelitian menunjukkan mayoritas pasien tumor orbita adalah laki laki sebesar $55,4 \% .^{2,7}$

Menurut data Cancer Research UK (2015), terjadi peningkatan kasus baru sebesar 738 (14\%) setiap tahunnya. Tumor orbita ganas di Inggris, dilaporkan sekitar 5.800 orang yang terdiagnosis hidup dari tahun 1991-2010. Dimana tumor tersebut diderita oleh pasien umur 80-84 tahun. Hal ini sesuai dengan hasil penelitian tumor orbita di PMN RS Mata Cicendo yang menyatakan bahwa tumor orbita diderita oleh pasien umur $>45$ tahun. Berdasarkan letak anatomisnya kasus terbanyak terjadi pada koroid retina, yaitu sebesar $60 \% .^{8}$
Hasil penelitian ini menunjukkan keterlibatan tumor orbita tersering adalah ocular sinistra sebesar $51,18 \%$ dimana mengenai palpebral sebesar 36\%. Hal sejalan dengan penelitian Kumar MS (2008) di India yaitu lesi jinak maupun ganas palpebra sering ditemukan pada pasien usia 40-an dan 50- an tahun. Hal ini hampir sama dengan hasil penelitian Henkind dan Friedman di Amerika Serikat yang mendapati 19,2\% jumlah lesi keganasan palpebra. Tumor palpebral ini mudah dikenali secara klinis apalagi yang bersifat jinak. ${ }^{9,10}$

Pada penelitian ini karakteristik terapi yang diberikan pada tumor orbita misalnya dengan biopsy insisi, biopsy eksisi, ekstirpasi, enukleasi, orbitotomi dan lain sebagainya. Penatalaksanaan tumor orbita beberapa tahun terakhir ini mengalami perkembangan yang signifikan. Dimana tujuan terapi ini untuk menyelamatkan fisik mata, fungsional penglihatan mata serta menyelamatkan nyawa pasien bila ternyatatumor orbita tersebut ganas. Pemberian terapi ini sedapat mungkin sedini mungkin sesuai dengan pertimbangan efektifitas, biaya yang sedikit, mampu menyelamatkan penglihatan dan kelangsungan hidup pasien. Terapi pada tumor orbita ini diberikan secara komperhensif dan koordinasi antara dokter terkait misalnya doketr mata, penyakit dalam, anak, radiologi, patologi anatomi sehingga memberikan hasil yang maksimal. Faktor yang mempengaruhi penatalaksaan tumor orbita misalnya jenis tumor, lokasi, ukuran, sifat 
pertumbuhan, usia riwayat penyakit lainnya,

factor psikologis dan riwayat pengobatan ${ }^{1,11}$

Angka kejadian tumor orbita sangat jarang, sekitar 3,5\%-4\%. Dari hasil diagnosis klinis penelitian tumor orbita ini didapatkan mayoritas lesi/tumor jinak sebesar $68,3 \%$ dimana kista menepati urutan pertama yaitu sebesar $22,4 \%$. Hasil ini sejalan dengan penelitian Tailor (2013) bahwa tumor orbita tersering adalah lesi jinak yang berupa kista dermoid. ${ }^{12}$

Namun dari hasil diagnosis klinis lesi tumor orbita ganas yang menduduki peringkat pertama adalah limfoma maligna dimana ditemukan sebanyak $22,4 \%$. Limfoma orbita ditemukan sekitar 50-60\% menurut penelitian Olsen (2019). Limfoma orbita ini sebagian besar berasal dari sel B (97\%), dimana ektranodal marginal zone limfoma (EMZL) merupakan subtype yang paling umum ditemukan yaitu sebesar 59\%. EMZL ini lebih sering terjadi padaperempuan sekitar $73 \%$ dan biasanya memiliki prognosis yang baik. ${ }^{13}$

Dari hasil penelitian menunjukan karakteristik tumor orbita berdasarkan hasil histopatologi menunjukkan lesi/tumor jinak yang paling seding sekitar $71,4 \%$ dimana hasil menunjukkan peradangan menduduki peringkat tertinggi yaitu sebesar $17 \%$. Namun dari hasil histopatologi lesi/tumor ganas orbita tersering adalah epithelial (43\%) dimana mayoritas disebabkan oleh SCC sebanyak (50\%). Jenis tumor orbita terbanyak pada palpebra yaitu basal sel karsinoma, tumor ini memiliki prognosis yang paling baik dibandingkan dengan squamous sel karsinoma, hal ini disebabkan karena sifat tumor ini yaitu tumbuh lambat dan hanya menyebabkan kerusakan melalui perluasan langsung dan jarang bermetastasis. Namun pada konjungtiva biasanya yang paling sering adalah skuamous sel karsinoma (SCC). Prognosis SCC ini tergantung pada ukuran lesi, temuan histopatologis, eksisi yang komplit. ${ }^{14,15}$

\section{SIMPULAN}

Karakteristik Pasien tumor orbita di PMN RS Mata Cicendo Tahun 2017-2018 sebanyak tumor orbita sebanyak 760 penderita dimana mayoritas umur $>45$ tahun (43,3\%), jenis kelamin laki-laki $(55,4 \%)$, keterlibatan mata ocular sinistra $(51,18 \%)$, denganlokasi tersering bukan di conjungtiva, palpebral dan retrobulbar $(36,8 \%)$, dengan diagnosis klinis tumor jinak $(68,3 \%)$ berupa kista $(22,4 \%)$, hasilhistopatologis terbanyak lesi tumor jinak $(71,4 \%)$ berupa peradangan $(17 \%)$.

\section{UCAPAN TERIMAKASIH}

Terima kasih saya ucapkan kepada Fakultas kedokteran Universitas Muhammadiah Purwokerto 
yang telah membantu memberikan dana pada

penelitian ini.

\section{DAFTAR PUSTAKA}

1. Soebagdjo, H.D. Onkologi Mata/Hendrian D. Soebagjo. -- Surabaya: Airlangga University Press, 2019.

2. Amemiya T., Hayashida H., and Dake Y. 2002. Metastatic orbital tumors in Japan: A review of the literature. Ophthalmic Epidemiology. 9(1); 35-47. DOI: 10. 1076/opep. 9. 1. 35. 1718.

3. Bonham, J., Ginat, D. T., \& Freitag, S. K. (2015). Imaging after orbital and intraocular oncology therapies. In Post-Treatment Imaging of the Orbit. https://doi.org/10.1007/978-3-662-44023-0_8

4. Course, C. S. (2015). Basic and Clinical Science Course. In American Academy of Ophthalmology.

5. Setia, M. (2016). Methodology series module 3: Cross-sectional studies. Indian Journal of Dermatology, 61(3), 261. https://doi.org/10.4103/0019-5154.182410

6. Sopiyudin Dahlan, M. (2016). Besar Sampel dalam Penelitian Kedokteran dan Kesehatan. In Epidemiologi Medika.

7. American Cancer Society. 2018. Cancer Facts \& Figures 2018. Atlanta. p. 1-76. Website:

https://www.cancer.org/content/dam/cancerorg/research/ cancer-facts-andstatistics/annual- cancer-facts-and-figures/2018/ cancer-facts-and-figures-2018.

8. Cancer Research UK. 2015. Eye Cancer Incidence Statistics. https://www. cancerresearchuk. org/health-professional/cancer-statistics/statisticsbycancer-type/eye-cancer/incidence\#heading.

9. Kumar M Santosh. Cytohistological study ofeyelid lesions and pitfalls in fine needle

10. aspiration cytology. Journal of Cytology 2008:25; 133-137

11. Wang J-K, Liao S-L, et al. Malignant eyelid tumours in Taiwan. Eye 2003;17: 216-220
12. Eldesouky, M. A., \& Elbakary, M. A. (2015). Clinical and imaging characteristics of orbital metastatic lesions among egyptian patients. Clinical Ophthalmology. https://doi.org/10.2147/OPTH.S87788

13. Tailor, T. D., Gupta, D., Dalley, R. W., Dirk Keene, C., \& Anza, Y. (2013). Orbital neoplasms in adults: Clinical, radiologic, and pathologic review. Radiographics. https://doi.org/10.1148/rg.336135502

14. Olsen, T. G., \& Heegaard, S. (2019). Orbital lymphoma. Survey of Ophthalmology. https://doi.org/10.1016/j.survophthal.2018.08.002

15. Khan, S. N., \& Sepahdari, A. R. (2012). Orbital masses: CT and MRI of common vascular lesions, benign tumors, and malignancies. Saudi Journal of Ophthalmology. https://doi.org/10.1016/j.sjopt.2012.08.001

16. Ushalatha B dan Sambasivarao. 2016 Role of CT in the Evaluation of Orbital Tumors. IOSR-JDMS. 15(4):1619 
Lampiran

Tabel 1. Karakteristik pasien berdasarkan usia

\begin{tabular}{ccc}
\hline Usia & Frekuensi & Persentase \\
\hline <17 tahun & 185 & 24,3 \\
$\mathbf{1 7 - 4 5}$ tahun & 245 & 32,2 \\
$>$ 45 tahun & 330 & 43,4 \\
\hline Total & 760 & 100
\end{tabular}

Tabel 2. Karakteristik pasien tumor orbita berdasarkan jenis kelamin

\begin{tabular}{ccc}
\hline Jenis Kelamin & Frekuensi & Persentase \\
\hline Laki-laki & 421 & 55,4 \\
Perempuan & 339 & 44,6 \\
\hline Total & 760 & 100 \\
\hline
\end{tabular}

Tabel 3. Karakteristik pasien tumor orbita berdasarkan keterlibatan Mata

\begin{tabular}{ccc}
\hline Mata yang terlibat & Frekuensi & Persentase \\
\hline OD (okular dextra) & 371 & 48,8 \\
OS (okular sinistra) & 389 & 51,18 \\
\hline Total & 760 & 100 \\
\hline
\end{tabular}

Tabel 4. Karakteristik pasien tumor orbita berdasarkan lokasi tumor Ocular dextra

\begin{tabular}{ccc}
\hline Lokasi tumor OD $\underline{\text { (okular dextra) }}$ & Frekuensi & Persentase \\
palpebra & 130 & 35 \\
conjungtiva & 88 & 23,7 \\
retrobulbar & 20 & 5,4 \\
lainnya & 133 & 35,8 \\
\hline Total & 371 & 100 \\
\hline
\end{tabular}

Tabel 5. Karakteristik pasien tumor orbita berdasarkan lokasi tumor Ocular sinistra

\begin{tabular}{ccc}
\hline Lokasi Tumor OS(okular sinistra) & Frekuensi & Persentase \\
\hline palpebra & 140 & 36 \\
conjungtiva & 77 & 19.8 \\
retrobulbar & 29 & 7.5 \\
lainnya & 143 & 36.8 \\
\hline Total & 389 & 100 \\
\hline
\end{tabular}


Tabel 6. Karakteristik pasien tumor orbita berdasarkan tindakan operasi

\begin{tabular}{ccc}
\hline Jenis Tindakan operasi & Frekuensi & Persentase \\
\hline Biopsi & 277 & 36,4 \\
Biopsi seksi & 14 & 1,8 \\
Biopsi insisi & 6 & 0,8 \\
Orbitomi & 21 & 2,8 \\
Enukleasi & 73 & 9,6 \\
Biopsi ekstirpasi & 92 & 12,1 \\
Biopsi eksisi & 91 & 12 \\
Lainnya & 186 & 24,5 \\
Total & 760 & 100
\end{tabular}

Tabel 7. Karakteristik pasien tumor orbita berdasarkan diagnosis klinis

\begin{tabular}{ccc}
\hline Diagnosis klinis & Frekuensi & Persentase \\
\hline Lesi/Tumor jinak & 519 & 68,3 \\
Lesi/Tumor ganas & 241 & 31,7 \\
\hline Total & 760 & 100 \\
\hline
\end{tabular}

Tabel 8. Karakteristik pasien tumor orbita berdasarkan diagnosis klinis lesi/tumor jinak

\begin{tabular}{ccc}
\hline Lesi/Tumor jinak & Frekuensi & Persentase \\
\hline Veruka & 24 & 4,6 \\
Kista & 116 & 22,4 \\
Nevus & 68 & 13,1 \\
Granuloma/Radang & 27 & 5,2 \\
Ocular surface & 34 & 6,6 \\
squamousneoplasm & & \\
(OSSN) & 92 & 17,7 \\
Massa & 115 & 22,2 \\
Lainnya & 43 & 8,3 \\
propotosis/massa & & 100 \\
retrobulbar & 519 & \\
Total & &
\end{tabular}


Tabel 9. Karakteristik pasien tumor orbita berdasarkan diagnosis klinis lesi/tumor ganas

\begin{tabular}{ccc}
\hline Lesi/Tumor ganas & Frekuensi & Persentase \\
\hline Squamous cell carcinoma(SCC) & 25 & 10,4 \\
Basal cell carcinoma (BCC) & 25 & 10,4 \\
Retinoblastoma & 50 & 20,7 \\
Melanoma & 27 & 11,2 \\
Sebaseous Carcinoma & 1 & 0,4 \\
Limfoma maligna/NHML & 55 & 22,8 \\
Meningioma & 11 & 4,6 \\
Glioma & 5 & 2,1 \\
Lainnya & 42 & 17,4 \\
Total & 241 & 100 \\
\hline
\end{tabular}

Tabel 10. Karakteristik pasien tumor orbita berdasarkan Hasil Histopatologi

\begin{tabular}{ccc}
\hline Hasil Histopatologi & Frekuensi & Persentase \\
\hline Lesi/Tumor jinak & 543 & 71,4 \\
Lesi/Tumor ganas & 217 & 28,6 \\
\hline Total & 760 & 100
\end{tabular}

Tabel 11. Karakteristik pasien tumor orbit berdasarkan Hasil histopatologi lesi/tumor jinak

\begin{tabular}{ccc}
\hline Lesi/Tumor jinak & Frekuensi & Persentase \\
\hline vitreal hemoragik & 11 & 2 \\
\hline radang & 92 & 17 \\
\hline epitelial cyst & 68 & 12,5 \\
\hline kista dermoid & 36 & 6,6 \\
\hline kista epidermoid & 17 & 3,1 \\
Ocular surface squamous & 29 & 5,3 \\
neoplasm $(\mathbf{O s}$ & 85 & 15,7 \\
\hline epitelial jinak lain & 76 & 14 \\
\hline nevus & 11 & 2 \\
\hline neurogenik jinak & 29 & 5,3 \\
\hline meseenkim jinak & 8 & 1,5 \\
\hline lakrimal jinak & 38 & 7 \\
\hline Vaskuler & 43 & 8 \\
\hline limfoid hiperplasia & 543 & 100 \\
\hline Total & &
\end{tabular}


Tabel 12. Karakteristik pasien tumor orbita berdasarkan Hasil histopatologi epithelial ganas

\begin{tabular}{ccc}
\hline Lesi/Tumor ganas & Frekuensi & Persentase \\
\hline Meningioma & 10 & 4,4 \\
Epitel ganas & 94 & 43,3 \\
Adneksa ganas & 18 & 8,3 \\
Kelenjar lacrimal ganas & 8 & 3,7 \\
Sarcoma & 7 & 3,2 \\
limfoma/limfoid ganas & 26 & 12 \\
Metastasis & 3 & 1,4 \\
Retinoblastoma & 51 & 23,5 \\
\hline Total & 217 & 100 \\
\hline
\end{tabular}

Tabel 13. Karakteristik pasien tumor orbita berdasarkan Hasil histopatologi adneksa ganas

\begin{tabular}{ccc}
\hline Adneksa ganas & Frekuensi & Persentase \\
\hline sebaseus carcinoma & 17 & 94,4 \\
Ductaleccrin carcinoma & 1 & 5,6 \\
\hline Total & 18 & 100 \\
\hline
\end{tabular}

Tabel 14. Karakteristik pasien tumor orbita berdasarkan Hasil histopatologi kelenjar ganas

\begin{tabular}{ccc}
\hline Kelenjar lacrimal ganas & Frekuensi & Persentase \\
\hline Adenoid kistik karsinoma (ADCC) & 3 & 37,5 \\
Mucoepidermoid carcinoma & 1 & 12,5 \\
Malignant mix tumor & 1 & 12,5 \\
Adenocarcinomalacrimal gland & 3 & 37,5 \\
\hline Total & 5 & 100 \\
\hline
\end{tabular}

